\title{
Selenium supplementation levels and sources in post- larvae Nile tilapia diet
}

\section{Níveis de suplementação e Fontes de Selênio na Dieta de pós-larvas de Tilápia do Nilo}

\author{
João Marcos Monteiro Batista ${ }^{1}$; Leonardo Augusto Fonseca Pascoal ${ }^{2 *}$; \\ José Humberto Vilar da Silva; Veruska Dilyanne Silva Gomes; Alda Lúcia de Lima \\ Amâncio2; Ricardo Romão Guerra4; Jorge Luiz Santos de Almeida3; \\ Chimenes Darlan Leal de Araujo5; Jonathan Mádson dos Santos Almeida3; \\ Jairo Janailton Alves dos Santos ${ }^{5}$
}

\section{Highlights}

Selenium acts in the development, growth and maintenance of fish homeostasis.

Selenium levels did not affect performance variables of post-larvae Nile tilapia. Selenium plays a key role in protecting cell membranes from oxidative damage.

\begin{abstract}
Fish larviculture exert great influence in the subsequent phases, in which nutrition is a basic prerequisite for success. Therefore, when it is in an intensified production system, it promotes the limitation of some minerals, making it necessary to supplement selenium in diets for post-larvae. The objective of this study was to evaluate selenium levels and sources in post-larvae Nile tilapia diets on muscle performance and histology. A total of 1,260 post-larvae with an initial average weight of $0.010 \mathrm{~g}$ were used, distributed in a completely randomized design in a factorial scheme with four supplementation levels $(0.6 ; 0.9 ; 1.2$ and $1.5 \mathrm{mg}$ of $\mathrm{Se} / \mathrm{Kg}$ ) and two sources (sodium selenite and selenium yeast), plus the negative control, with 35 post-larvae Nile tilapia used per experimental unit. The physical-chemical parameters of water quality were within those recommended for tilapia cultivation. Feed consumption $(p<0.05)$ and hepatosomatic index $(p<0.05$ ) were affected by the source used. Effects of supplemented selenium levels and sources were not observed for the other performance variables. Higher values for final height, final width, specific

1 Doctoral Student of the Postgraduate Program in Animal Science, School of Veterinary and Animal Science, Universidade Federal de Goiás, UFG, Goiânia, GO, Brazil. E-mail: joao_92trimonteiro@hotmail.com

2 Profs., Departament of Animal Science, Universidade Federal da Paraíba, UFPB, Campus III, Bananeiras, PB, Brazil. E-mail: leonardo@cchsa.ufpb.br; vilardasiva@yahoo.com.br; alda.amancio@yahoo.com.br

${ }^{3}$ Doctoral Students of the Postgraduate Program in Animal Science, UFPB, Areia, PB, Brazil. E-mail: veruska_sgomes@ yahoo.com.br; luizjorgealmeida@gmail.com; jonathan_madson@hotmail.com

4 Prof., Departament of Veterinary Sciences, UFPB, Campus II, Areia, PB, Brazil. E-mail: ricardo@cca.ufpb.br

${ }^{5}$ Master Students of the Postgraduate Program in Agrifood Technology, UFPB, Areia, PB, Brazil. E-mail: chimenesdarlan@gmail.com; jjasnp@hotmail.com

* Author for correspondence
\end{abstract}

Received: July 13, 2021 - Approved: Nov. 18, 2021 
development rate and protein efficiency rate were found $(p<0.05)$ when comparing the control diet with diets containing the sodium selenite source. No effects on muscle fiber morphometry were observed $(p>$ 0.05 ) in the studied variables. It is concluded that $0.6 \mathrm{mg}$ of selenium in the diet, regardless of the source used, met the mineral requirement for post-larvae Nile tilapia.

Key words: Muscle fiber. Performance. Selenomethionine. Selenium yeast. Selenoprotein.

\section{Resumo}

A larvicultura de peixes exerce grande influência nas fases subsequentes, onde a nutrição é um prérequisito básico para o sucesso. Portanto, quando está em sistema de produção intensificada, promove a limitação de alguns minerais, sendo necessária a suplementação de selênio em dietas para pós-larvas. Objetivou-se avaliar níveis e fontes de selênio em dietas para pós-larvas de tilápia do Nilo, sobre o desempenho e histologia muscular. Utilizou-se 1260 pós-larvas, peso médio inicial 0,010 g, distribuídas em delineamento inteiramente casualizado, em esquema fatorial com quatro níveis de suplementação $(0,6 ; 0,9 ; 1,2$ e 1,5 mg/kg de Selênio) e duas fontes (Selenito de sódio e Selênio levedura), mais o controle negativo, utilizou-se 35 pós-larvas por unidade experimental. Os parâmetros físico-químicos de qualidade da água, apresentaram-se dentro do recomendado para tilápias. O consumo de ração $(p<0001)$ e índice hepatossomático $(\mathrm{p}<0,05)$, foram afetados pela fonte utilizada. Para as demais variáveis de desempenho, não foram observados efeitos dos níveis e das fontes de selênio suplementadas. Quando comparada dieta controle as dietas contendo a fonte selenito de sódio verificou-se $(p<0,05)$ maiores altura final, largura final, taxa de desenvolvimento especifico e taxa de eficiência proteica. Não foram evidenciados $(p>0,05)$ efeitos sobre morfometria das fibras musculares nas variáveis estudadas. Conclui-se que $0,6 \mathrm{mg}$ de selênio na dieta, independente da fonte utilizada atendeu a necessidade do mineral para pós-larvas de tilápia do Nilo.

Palavras-chave: Desempenho. Fibra muscular. Selenometionina. Selênio levedura. Selenoproteína.

\section{Introduction}

Fish larviculture and fingerling stage are described as the phases which comprise the larvae hatching to the commercial size fingerlings. It is in this stage that they are called fry once their sexual organs are developed and they have grown their scales and fins and constitutes a period which varies depending on the species, temperature and nutrition (Meurer, Hayashi, Boscolo, Schamber, \& Bombardelli, 2005). Adequate nutrition in this phase has great influence, being a basic prerequisite for success in the subsequent cultivation phases. These are the most important fish farming phases for obtaining animals in quantity and quality (Hayashi, Boscolo, Soares, \& Meurer, 2002).

Therefore, some limiting nutritional factors must be taken into account, especially in the post-larvae phase which require high proteinandenergy, sothat theydonotnegatively interfere in the optimum performance of fish species. We can highlight mineral nutrition among these factors, especially in an intensified production system which can promote limitations of some minerals, causing a deficiency in the fish. Therefore, it is necessary to supplement selenium in post-larvae diets in intensive systems (Takahashi et al., 2017) to provide good structural conformation and 
ideal immunological conditions (Schulter \& Vieira, 2018).

Selenium acts on fish development, growth and homeostasis maintenance, as well as playing a fundamental role in protecting cell membranes and oxidative damage through regulating selenoenzymes which act together with glutathione peroxidase, which is one of the regulating selenoproteins of the intracellular redox environment (Rathore et al., 2021). Thus, they protect neutrophils originated from oxygen, which are produced to eliminate foreign organisms ingested by fish (Lin \& Shiau, 2005). This essentiality of selenium in the immune system is due to being a selenocysteine component which participates in biochemical reactions in the cell; it is almost completely ionized under physiological conditions, and consequently is considered an extremely efficient catalyst (Prauchner, 2020).

However, the bioavailability and absorption of selenium in the fish's body can be influenced by both the chemical formula and by the sources due to different purifications, which can directly affect cultivated fish performance. Therefore, seleniomethionine is the common organic form in the industry, with easy absorption by enterocytes through active transport mechanisms, and with bioavailability around 98\%. The inorganic form is absorbed by passive transport with bioavailability around 90\% (Schrauzer, 2001).

Selenium is a widely-distributed element in nature and is found in the environment in the form of selenates (Se6+), selenites (Se4+) and selenides (Se2+), and rarely as a selenium element (Se0). Selenium in its organic form is found in trace amounts in most plants and animal tissue. It has been evidenced in studies that minerals complexed with organic molecules are more bioavailable than those in inorganic form (Pilarczyk et al., 2019). In addition, some studies overestimate the recommended values of selenium in fish diets, yet it has shown satisfactory results without harming productivity (Takahashi et al., 2017). In this context, this study aimed to evaluate different selenium supplementation levels and sources (sodium selenite and selenium yeast) in post-larvae Nile tilapia diets.

\section{Materials and Methods}

The experiment was carried out at the Aquaculture Laboratory of the Center for Human, Social and Agrarian Sciences, Campus III, Bananeiras-PB of the Federal University of Paraíba, and lasted for 30 days. The experimental protocol No. 7153120220 was approved by the Ethics Committee for the Use of Animals (CEUA) of the Federal University of Paraíba.

\section{Experimental facilities, animals and diets}

A total of 1,260 post-larvae Nile tilapia (Oreochromis niloticus) were used to perform the performance test, with an initial average live weight of approximately 0.010 $\pm 0.002 \mathrm{~g}$ from a local commercial fish farm. The fish weight was obtained by weighing groups together and then divided by the number of animals in each group, thus it was possible to obtain an approximate average. The animals were distributed in a completely randomized design in a factorial scheme, with four selenium supplementation levels (0.6; $0.9 ; 1.2$ and $1.5 \mathrm{mg}$ of selenium $/ \mathrm{kg}$ of feed) and two selenium sources (sodium selenite and yeast selenite), and control treatment, totaling nine treatments and four repetitions. 
Thus, nine equal isoproteic and isoenergetic experimental diets were elaborated.

The post-larvae were distributed in 36 fiberglass aquariums with an individual water level in each aquarium of $20 \mathrm{~L}$, and each with 35 post-larvae tilapia at a density of 1.75 fish/L. The aquariums had continuous water renewal through an individual water recirculation system for each selenium source to avoid interference from the sources. Each system additionally had biological filters, in which each filter obtained a maturation period of one month before beginning the trial period.

The physical-chemical parameters of water quality were within those recommended for tilapia production (Table 1). The water temperature was maintained between 25 to $27.51{ }^{\circ} \mathrm{C}$ through heaters with an automatic Acepet/Risheng thermostat of 250 to $300 \mathrm{~W}$ (220v). All water used in the experiment came from an artesian well. The dissolved oxygen present in the water remained in the range between 4 and $16 \mathrm{mg} \cdot \mathrm{L}^{-1}$. The $\mathrm{pH}$ remained in the range between 6.5 to 9.0. Thus, the alkalinity and hardness values entered were above $20 \mathrm{mg} \cdot \mathrm{L}^{-1}$, and carbon gas was below $20 \mathrm{mg} \cdot \mathrm{L}^{-1}$.

The control diet (Table 2) was formulated according to the nutritional recommendations described by Furuya (2010) for all nutrients, except for selenium values. The ingredients for preparing the rations were ground in a knife-type mill, sieved with a 0.6 $\mathrm{mm}$ sieve, mixed and $60 \mathrm{mg} / \mathrm{kg}$ of the hormone 17- $\alpha$-methyl testosterone were subsequently added to the rations.

Next, mineral supplements were formulated with the different selenium sources and levels for supplementing the different selenium levels in the diets (Table 3 and 4) and were added at the same level in the diet according to the treatments. However, there was no selenium supplementation in the control diet composition (Table 3).

\section{Table 1}

Water analysis of the water recirculation system used in the experimental test with different sources of selenium for post-larvae Nile tilapia

\begin{tabular}{|c|c|c|c|c|c|c|}
\hline \multirow{4}{*}{ Parameters } & \multicolumn{3}{|c|}{ Sodium selenite source } & \multicolumn{3}{|c|}{ Source Selenium Yeast } \\
\hline & \multicolumn{3}{|c|}{ Weeks } & \multicolumn{3}{|c|}{ Weeks } \\
\hline & 1st & 2nd & 3rd & 1st & 2nd & 3rd \\
\hline & \multicolumn{6}{|c|}{ Mean \pm standard deviation } \\
\hline DO (mg. $\left.\mathrm{L}^{-1}\right)$ & $5.98 \pm 0.39$ & $6.25 \pm 0.13$ & $6.93 \pm 0.46$ & $5.80 \pm 0.16$ & $5.80 \pm 0.23$ & $6.63 \pm 0.56$ \\
\hline $\begin{array}{c}\text { Temperature } \\
\left({ }^{\circ} \mathrm{C}\right)\end{array}$ & $25 \pm 0.82$ & $27.25 \pm 0.50$ & $27.50 \pm 1.00$ & $25 \pm 0.82$ & $26.75 \pm 0.96$ & $27.51 \pm 0.56$ \\
\hline $\mathrm{pH}$ & $7.95 \pm 0.17$ & $8.1 \pm 0.22$ & $7.86 \pm 0.17$ & $8.1 \pm 0,00$ & $7.93 \pm 0.15$ & $7.92 \pm 0.09$ \\
\hline $\begin{array}{l}\text { Total alkalinity } \\
\text { (mg/L) }\end{array}$ & $37.5 \pm 11.21$ & $34.75 \pm 3.40$ & $32 \pm 1.63$ & $36 \pm 8.83$ & $31.75 \pm 2.22$ & $31.52 \pm 1.76$ \\
\hline $\begin{array}{l}\text { Carbon dioxide } \\
\text { (mg/L) }\end{array}$ & $11 \pm 1.83$ & $9.25 \pm 1.50$ & $9.25 \pm 3.20$ & $7.50 \pm 2.38$ & $9.25 \pm 2.63$ & $8.69 \pm 0.94$ \\
\hline $\begin{array}{l}\text { Total hardness } \\
\text { (mg/L) }\end{array}$ & $39.50 \pm 6.40$ & $39 \pm 8.72$ & $30 \pm 2.31$ & $39 \pm 7.39$ & $39 \pm 4.76$ & $30.55 \pm 3.87$ \\
\hline
\end{tabular}

*DO-dissolved oxygen, pH-potential Hydrogenionic. 


\section{Table 2}

\section{Food and nutritional composition of the diet for post-larvae Nile tilapia}

\begin{tabular}{|c|c|}
\hline Ingredients & $\mathrm{g} / \mathrm{kg}$ \\
\hline Poultry offal meal & 35182.4 \\
\hline Corn meal & 27285.3 \\
\hline Soybean meal $45 \%$ & 17760.4 \\
\hline Fish meal 60\% & 11664.8 \\
\hline Soybean oil & 7400.7 \\
\hline Mineral Premix & 2500 \\
\hline Vitaminic Premix & 2500 \\
\hline L-threonine & 111 \\
\hline Ascorbic acid & 59.9 \\
\hline L-tryptophan & 35.6 \\
\hline Total & 100.000 \\
\hline Nutrient & The amount \\
\hline Digestible energy (kcal/g) & 3.6000 \\
\hline Available phosphorus (\%) & 1.2514 \\
\hline Total lysine (\%) & 2.2000 \\
\hline Met. + Total cystine (\%) & 1.3200 \\
\hline Total methionine (\%) & 0.7529 \\
\hline Digestible protein (\%) & 38.0000 \\
\hline Selenium (mg/kg) & 0.0788 \\
\hline Total threonine (\%) & 1.7000 \\
\hline Total tryptophan (\%) & 0.4300 \\
\hline Vit. C (mg/kg) & 600.0000 \\
\hline
\end{tabular}

*Vitamin premix: vitamin A - 5.000,0 Ul. $\mathrm{Kg}^{-1}$; vitamin B1 - $10 \mathrm{mg} . \mathrm{kg}^{-1}$; vitamin B2 - $10 \mathrm{mg} . \mathrm{Kg}^{-1}$, vitamin B6 - $10 \mathrm{mg} \cdot \mathrm{Kg}^{-1}$, vitamin B12 - 20 mg. Kg ${ }^{-1}$, vitamin C 100 mg. Kg-1, vitamin D3 - 100,0 Ul. $\mathrm{Kg}^{-1}$, vitamin E - 50,0 Ul. $\mathrm{Kg}^{-1}$, vitamin K - 5,0 mg. $\mathrm{Kg}^{-1}$, vitamin - 0,05 mg. $\mathrm{Kg}^{-1}$, niacin - $150 \mathrm{mg} \cdot \mathrm{Kg}^{-1}$, choline chloride - 2.000,0 mg. $\mathrm{Kg}^{-1}$. Mineral Premix was formulated according to the requirements proposed by Ferrari et al. (2004) for copper; Kleemann (2002) for iron, zinc and iodine; Hung, Tu and Wang (2007) manganese; Yamamoto (2011) for cobalt; NRC (2011) for magnesium.

The sources of selenium used in the diets were selenium yeast acquired from YESMINERALS SELENIO ${ }^{\circledR}$, which is a complex of amino acids linked to a molecule of selenium, and which presented a concentration in the product of $300,000 \mathrm{mg}$ of Se/kg, therefore less purified. The other source added to the diets was sodium selenite acquired from DINÂMICA $^{\circledR}$, which had $2,000 \mathrm{mg}$ of $\mathrm{Se} /$ $\mathrm{Kg}$ concentration in the product, making it possible to observe a greater purification of this source for addition to the diets (Table 4). 


\section{Table 3}

Nutritional and quantitative composition of the mineral supplement for post-larvae Nile tilapia

\begin{tabular}{|cccc|}
\hline Microminerals & Requirement $(\mathrm{mg} / \mathrm{kg})$ & Concentration $(\%)$ & Supplement $(\mathrm{g} / 25 \mathrm{~g})$ \\
\hline Copper & 4.00 & 25.70 & 0.1556 \\
\hline Iron & 60.00 & 20.70 & 2.8986 \\
\hline Manganese & 150.00 & 32.50 & 4.6148 \\
\hline Zinc & 150.00 & 22.74 & 6.5963 \\
\hline Cobalt & 10.00 & 21.91 & 0.4565 \\
\hline Magnesium & 1.26 & 10.36 & 0.1216 \\
\hline lodine & 5.00 & 75.90 & 0.0659 \\
\hline Total minerals $(\mathrm{mg}) /(\mathrm{g})$ & & & 14.093 \\
\hline Vehicle (Kaolin) $(\mathrm{mg}) /(\mathrm{g})$ & & & 10.0907 \\
\hline Premix Mineral & & & 25.0000 \\
\hline
\end{tabular}

*Mineral Premix was formulated according to the requirements proposed by Ferrari et al. (2004) for copper; Kleemann (2002) for iron, zinc and iodine; Hung et al. (2007) manganese; Yamamoto (2011) for cobalt; NRC (2011) for magnesium. The sources for the micro minerals were: Copper $\left(\mathrm{CuSO}_{4 \cdot 5} \mathrm{H}_{2} \mathrm{O}\right)$; Iron $\left(\mathrm{FeCl}_{3}\right)$; Manganese $\left(\mathrm{MnSO}_{4}\right) ; \mathrm{Zinc}\left(\mathrm{ZnSO}_{4 \cdot 7} \mathrm{H}_{2} \mathrm{O}\right)$; Cobalt $\left(\mathrm{CoSO}_{4 \cdot 7} \mathrm{H}_{2} \mathrm{O}\right) ;$ Magnesium $\left(\mathrm{MgSO}_{4 \cdot 7} \mathrm{H}_{2} \mathrm{O}\right)$; lodine (KI).

\section{Table 4}

Selenium contents of experimental diets for post-larvae Nile tilapia according to the level and source used

\begin{tabular}{|cccc|}
\hline Selenium sources & Requirement $(\mathrm{mg} / \mathrm{kg})$ & Concentration $(\%)$ & Supplement $(\mathrm{mg} / 25 \mathrm{~g})$ \\
\hline \multirow{3}{*}{ Sodium selenite } & 0.6 & 30 & 0.020 \\
& 0.9 & 30 & 0.030 \\
& 1.2 & 30 & 0.040 \\
Selenium yeast & 1.5 & 30 & 0.050 \\
& 0.6 & 0.2 & 3.000 \\
& 0.9 & 0.2 & 4.500 \\
& 1.2 & 0.2 & 6.000 \\
\hline
\end{tabular}

*The selenium requirements for supplements were in accordance with the recommendations of the Brazilian Tables for Tilapia nutrition, Furuya (2010). Yeast selenium had a concentration of $300,000 \mathrm{mg} \mathrm{se} / \mathrm{kg}$ of product, and sodium selenite had a concentration of $2,000 \mathrm{mg} \mathrm{se} / \mathrm{kg}$ of product.

A batch of post-larvae was removed at the beginning of the experiment to perform the initial biometry. The post-larvae were fed daily with bran feed, which was offered at will seven times a day (8:00 am, 9:30 am, 11:00 am, 1:00 pm, 2:30 pm, 4:00 pm, and 5:30 pm). The aquarium bottom siphoning was performed daily at 7:00 am and 4:30 pm before the first 
and last feeding, respectively, replacing about $20 \%$ of the total volume of water for each siphoning.

\section{Productive performance}

The fish were weighed and measured at the end of the experiment with the following variables being evaluated: daily weight gain $(D W G)=($ final weight - initial weight)/time (in days); daily feed consumption (DFC) = food consumption/time (in days); apparent feed conversion (AFC) = food consumption/ total weight gain; final length $(F L)$; final width $(\mathrm{FW})$; specific growth rate $(\mathrm{SGR})=$ (In final weight - In initial weight) $\times 100 /$ time; specific development rate $(\mathrm{SDR})=[((\mathrm{In}$ final total length - In initial total length)/time) x 100]; fulton condition factor $=$ [final weight/(final length) 3] $\mathrm{x}$ 100; protein efficiency rate (TEP) = weight gain/(feed consumption $\times$ CP\% of the diet); survival $(S)=100$ * (initial number of fish - final number of fish)/initial number of fish.

Next, five fingerlings were removed from each aquarium at the end of the experimental period of 30 days for liver collection. All fish were anesthetized after 24 hours of fasting with $100 \mathrm{mg} / \mathrm{L}$ of ethyl 3-aminobenzoate methanesulfonate (MS222, Sigma-Aldrich, 98\% tricaine, Missouri, USA), in which the fingerling were sacrificed according to ethical slaughter principles. Then, the liver was removed, weighed and the hepatosomatic index (HSI) was calculated using the formula: HSI (liver weight/postlarvae weight) $\mathrm{x}$ 100).

\section{Muscle fiber analysis}

First, four samples of approximately 1 $\mathrm{cm}$ referring to the part of the body of the fish were collected to study the muscular structure of tilapia fingerlings. The body segments of the fish were fixated in a Metacarn solution (containing 60\% methanol, 30\% chloroform and $10 \%$ acetic acid) for a period of 12 hours, and kept refrigerated. Then, the samples were soaked in a $70 \%$ alcohol solution. Next, the samples were taken to the Histology Laboratory of the Center for Agricultural Sciences (CCA)/UFPB, Campus II in the city of Areia/UFPB, to perform the morphometric analysis of the muscle in the fish's body to make the histological slides.

The samples remained for about 24 hours in a $70 \%$ alcohol solution, then they were washed in running water for five minutes and dehydrated in an increasing series of alcohols and passed through a xylol battery, and finally included in paraffin at the end of this step. The paraffin blocks were later microtomed to make the histological slides.

The slides referring to the fish's body to assess the muscle fiber of the fish were stained using hematoxylin/eosin staining and periodic acid-Schiff (PAS) + hematoxylin histochemistry, respectively, to evaluate the muscle fiber length (MFL) and muscle fiber diameter (MFD) variables. Thus, four fish slides were made to measure the muscle fibers, with each fish obtaining five measurements of muscle fibers. Measurements were performed on the dorsum muscle tissue where greater muscle deposition is present in the fish.

Next, an Olympus BX53 light microscope and Zeiss Axion camera were used to perform the histological slide readings, coupled with the Cellsens Dimension digital image capture program. The absorptive area (AA) was determined according to the methodology described by Silva (2015). 


\section{Statistical analysis}

The data were subjected to analysis of variance and the PROC GLM procedure with a $4 \times 2$ factorial was used in which the means were subjected to regression analysis to observe whether there was a difference between the levels. In addition, the means of each of the sources were compared with the control treatment by orthogonal contrasts $4 \times 2+1$, all using the SAS software program (Version University).

\section{Results and Discussion}

\section{Productive performance}

For the values presented in Table 5, no differences were observed $(p>0.05)$ for any of the performance variables of the postlarvae between selenium levels, regardless of the source. However, an effect of selenium sources on feed consumption $(p<0.0001)$ and hepatosomatic index $(p<0.05)$ was observed.

Table 4

Selenium contents of experimental diets for post-larvae Nile tilapia according to the level and source used

\begin{tabular}{|c|c|c|c|c|c|c|c|c|c|c|c|}
\hline \multirow{2}{*}{$\begin{array}{c}\text { Selenium } \\
\text { Sources }\end{array}$} & \multicolumn{11}{|c|}{ Variables } \\
\hline & $\mathrm{FI}$ & WG & $\mathrm{FC}$ & $\mathrm{FH}$ & FW & S & $\mathrm{HI}$ & SGR & SDR & FCF & PER \\
\hline SES & 0.0150 & 0.32 & 1.70 & 7.31 & 4.06 & 66.79 & 1.94 & 1.05 & 51.71 & 0.0021 & 60.15 \\
\hline SEY & 0.0157 & 0.30 & 2.05 & 7.41 & 4.15 & 64.64 & 2.67 & 0.99 & 49.20 & 0.0022 & 53.87 \\
\hline Levels & $\mathrm{CR}$ & $\mathrm{GP}$ & $\mathrm{CA}$ & $\mathrm{AF}$ & LF & $S$ & IHS & TCE & TDE & FCF & TEP \\
\hline 0.6 & 0.0153 & 0.30 & 2.15 & 7.48 & 4.13 & 66.79 & 2.34 & 0.98 & 50.94 & 0.0020 & 55.31 \\
\hline 0.9 & 0.0154 & 0.29 & 1.87 & 7.13 & 3.98 & 66.07 & 2.14 & 0.98 & 48.07 & 0.0023 & 54.85 \\
\hline 1.2 & 0.0154 & 0.32 & 1.73 & 7.39 & 4.13 & 63.57 & 2.38 & 1.07 & 52.14 & 0.0021 & 59.20 \\
\hline 1.5 & 0.0154 & 0.32 & 1.76 & 7.43 & 4.17 & 66.43 & 2.33 & 1.05 & 50.68 & 0.0022 & 58.70 \\
\hline \multirow{2}{*}{ Effect } & \multicolumn{11}{|c|}{ Variables } \\
\hline & $\mathrm{FI}$ & WG & FC & $\mathrm{FH}$ & FW & $S$ & $\mathrm{HI}$ & SGR & SDR & FCF & PER \\
\hline Level & ns & ns & ns & ns & ns & ns & ns & ns & ns & ns & ns \\
\hline Source & * & ns & ns & ns & ns & ns & * & ns & ns & ns & ns \\
\hline $\begin{array}{l}\text { Level* }^{*} \\
\text { Source }\end{array}$ & ns & ns & ns & ns & ns & ns & ns & ns & ns & ns & ns \\
\hline MSE & 0.0015 & 0.072 & 0.715 & 0.459 & 0.283 & 9.119 & 0.659 & 0.241 & 3.843 & 0.00029 & 13.371 \\
\hline
\end{tabular}

${ }^{*} \mathrm{FI}$ - feed intake, WG- weight gain, FH- final height, FW- final width, FC-feed conversion, S- survival, HI- hepatosomatic index, SGR- specific growth rate, SDR- specific development rate, FCF- fulton condition factor, PER- protein efficiency rate, MSE- mean standard error, SES - sodium selenite, SEY - selenium yeast, Ns - not significant * $P<0.05$.

It was found that fish which received the selenium yeast source in the diet increased feed consumption when compared with the fish which received sodium selenite $(p<0.05)$. Therefore, it is possible to indicate a supplementation of $0.6 \mathrm{mg}$ of selenium $/ \mathrm{kg}$ in the diet for post-larvae Nile tilapia, since the levels above $0.6 \mathrm{mg}$ of selenium $/ \mathrm{kg}$ in the diet did not present a significant difference for the variables, regardless of the source 
used in the diets. According to Takahashi et al. (2017), the need for selenium can supposedly be increased in intensive production systems since there are immunosuppressive factors of oxidative stress, which can compromise performance and immune responses, and in this sense an increase in consumption in diets containing selenium yeast.

Survival was approximately $65.72 \%$, indicating an average mortality rate of $34.28 \%$; this is in agreement with De Bock et al. (2020) who obtained $65 \%$ survival for the post-larvae phase, in which the authors point out that mortality in this phase can be due to several factors such as genetic, environmental, temperature, adaptation to the experimental system, among others. Lee, Nambi, Won, Katya and Bai (2016) suggested that ideal selenium levels in diets for juvenile tilapia are above 1.06 and below 2.06 mg selenium/ $\mathrm{kg}$ of feed, and considered the toxic level of dietary selenium between 6.31 to $14.7 \mathrm{mg}$ selenium $/ \mathrm{kg}$ of feed. With this, we can verify that the selenium range used in the present study was within the ideal range, and proving a non-difference between the supplemented levels. In supplementing selenium for tilapia, (Schram, Pedrero, Cámara, Heul, \& Luten, 2008) reported that they observed a higher level of fillet in fish that received $8.5 \mathrm{mg}$ selenium/kg supplementation in the diet.

The hepatosomatic index was not altered $(p>0.05)$ by the selenium level supplementation (Table 5), however it was evidenced that the hepatosomatic index values of the post-larvae which received the selenium yeast source in the diets were higher ( $p<0.05$ ) when compared to the post-larvae that received the diet containing the inorganic source.
The hepatosomatic index corresponds to an increase in the fish liver, and it is known that the liver performs metabolic processes; thus, it is responsible for producing and regulating reactive oxygen species in the liver tissue, and on the other hand for tissue damage (Rui, 2014; Khalil, Mansour, Goda, Omar, \& 2019). In turn, it can reflect in improved lipid metabolism of the fish supplemented with selenium yeast in the diets, raising the mRNA levels of the fatty acid desaturase in the liver in post-larvae (Khalil et al., 2019).

The fish's liver is the main organ where selenium metabolism and deposition occur, where the selenium is transformed into hydrogen selenide and later on selenocysteine, which is then incorporated into selenoprotein. Thus, selenium supplementation in the diet can increase the presence of selenocysteine in the liver, and with this possibly greater selenium deposition in the liver and muscle in the post-larvae (Sele, Ornsrud, Sloth, Berntssen, \& Amlund, 2018). According to (Yamashita, Yabu, Yamashita, \& 2010), selenide excess in fish metabolism can lead to forming selenonein, which is the way that selenium can accumulate in the liver and muscles, considering that selenomethionine is the main species of selenium found in fish muscle (Jagtap, Maher, Krikowa, Ellwood, \& Foster, 2016; Sele, Ornsrud, Sloth, Berntssen, Amlund, \& 2018).

Fulton's condition factor remained within the ideal range for the species during the post-larvae cultivation period, in which it presented a condition average between 0.0020 to 0.0023 . In this context, the present study did not find any negative interference in the fingerling performance according to Fulton's condition factor, since the post-larvae 
supplemented with the different selenium sources were found in suitable physiological and nutritional conditions for the cultivation phase.

Orthogonal contrasts were performed to assess the difference between the control diet without selenium supplementation (Table 6), by which it was found that there was no statistical difference ( $p>0.05)$ in the control treatment versus selenium sources, nor for sodium selenite versus selenium yeast during the post-larvae tilapia phase for the weight gain, feed conversion, specific growth rate, Fulton's condition factor and survival variables.

However, feed intake was increased $(P<0.05)$ when the animals received diets containing selenium sources when compared to a diet without supplementation. In addition, it was found that the consumption was higher when fish were fed diets containing selenium yeast when comparing the selenium supplementation sources.

An explanation for the higher feed consumption and higher hepatosomatic index in post-larvae that received selenium yeast in the diet is due to the selenium complexed to the organic molecule being easily absorbed into the organism and having a greater capacity to deposit in the tissues where the liver is the first selenium deposition site for post-larvae. Thus, they may have consumed a greater amount of feed due to possible mobilization of yeast selenium in the fish livers in an attempt to improve the physiological attendance of selenium as a regulation of antioxidant factors, and consequently increase deposition in the liver and muscle (Zhan, Wang, Zhao, Li, \& Xu, 2007).

\section{Table 6}

Performance evaluation of post-larvae Nile tilapia by contrasts, supplemented or not with selenium in diets

\begin{tabular}{|cccccccc|}
\hline \multirow{2}{*}{ VAR } & Control & \multicolumn{2}{c}{ Source } & \multicolumn{3}{c|}{ P>0.05 - Contrast } \\
\hline FI (g) & 0.0154 & 0.0150 & 0.0157 & 0.0122 & 0.0010 & $<.0001$ & 0.0185 \\
\hline WG (g) & 0.2501 & 0.3156 & 0.2968 & 0.2389 & 0.1024 & 0.4485 & 0.0693 \\
\hline FC & 2.2117 & 1.7041 & 2.0480 & 0.6759 & 0.1995 & 0.1696 & 1.7262 \\
\hline FH (mm) & 6.7667 & 7.3072 & 7.4072 & 0.0174 & 0.0417 & 0.5370 & 0.2807 \\
\hline FW (mm) & 3.7892 & 4.0557 & 4.1525 & 0.0263 & 0.0962 & 0.3305 & 0.2765 \\
\hline SGR (\%) & 0.8336 & 1.0520 & 0.9892 & 0.2391 & 0.1025 & 0.4489 & 0.2311 \\
\hline SDR (\%) & 45.6768 & 51.7088 & 49.2023 & 0.1140 & 0.0095 & 0.0774 & 3.8615 \\
\hline FCF (\%) & 0.0021 & 0.0021 & 0.0022 & 0.5600 & 0.8761 & 0.4996 & 0.0003 \\
\hline PER (\%) & 46.4088 & 60.1549 & 53.8723 & 0.3102 & 0.0670 & 0.1782 & 0.1472 \\
\hline HI (\%) & 2.1737 & 1.9352 & 2.6683 & 0.2276 & 0.5563 & 0.0031 & 0.6362 \\
\hline S (\%) & 65.000 & 66.7857 & 64.6429 & 0.9425 & 0.9377 & 0.81227 & 8.7703 \\
\hline
\end{tabular}

*WG- weight gain, FI- feed intake, FH- final height, FW- final width, FC-feed conversion, S- survival, HI- hepatosomatic index, SGR- specific growth rate, SDR- specific development rate, FCF- fulton condition factor, PER- protein efficiency rate, MSE- mean standard error, VAR- variables, SES - sodium selenite, SEY - selenium yeast. CONT- control. 
The post-larvae that received diets supplemented with selenium sources had higher final length compared to the control diet. Moreover, a better final width was observed for the fish that received selenium yeast in the diets when compared to the diet without supplementation. Therefore, we can observe that fish diets supplemented with selenium causes tissue growth due to an improvement in the level of tissue selenzyme activities, as it reaches an overcompliance with the supplemented dietary selenium requirements, thus increasing the metabolic selenium levels in post-larvae, improves the specific selenocysteine and selenomethionine incorporation, and consequently increases the selenoprotein (Katarzyna, Taylor, Szpunar, Lobinski, \& Sunde, 2020). Incorporating selenium in fish nutrition is mainly essential because it is part of selenoprotein, which performs biological functions in the body; thus, selenium levels in the diet are crucial for optimal growth and good health of fish (Zhang, Feng, Chan, \& Larssen, 2014).

Differences were also found in the hepatosomatic index, except that in this case thelowestresultwas found $(p<0.05$ ) for sodium selenite compared to selenium yeast, but they did not differ from the control treatment. The increase in the hepatosomatic index for treatments containing yeast selenium may have been caused by the dose-dependent effect, meaning that the supplemented selenium concentrations in the diets tend to stimulate an increase in the reactions in the fishes' liver due to the fact that the liver is the central organ for selenium metabolism; thus, there is a greater metabolism of nutrients, and a consequent increase in liver tissue (Lee et al., 2016). These same authors also mention that hepatic tissue is the main metabolic organ of selenium in comparison to the branchial and muscular tissues.

A better specific development rate was observed for fish that received selenium supplementation in their diets compared to fish that did not receive selenium supplementation in their diets. The fish obtained a higher specific development rate $(p<0.05)$ when they received the diets with sodium selenite compared to the control diet (without Se supplementation). Better fish development in the present study may be slightly related to the protective role of selenium in combating ROS production in the muscles of animals, in which it reduces damage to muscle fibers which is directly influenced by the HUFA increase in diets (Betancor et al., 2012). However, it needs to be taken into account that the muscle growth of the fish presents itself in a constant process of hypertrophy and muscle hyperplasia throughout their entire life cycle (Mansour, Goda, Omar, Khalil, \& Esteban, 2017).

Selenium supplementation nutritionally improves protein efficiency by reducing the antinutritional factors of the feed and oxidative stresses, consequently increasing the content of growth hormone taurine in the fish organism (Wang et al., 2018).

As can be seen in Table 7, the length, diameter and muscle fiber area values in the muscle tissue of the Nile tilapia fingerlings were not affected by diets supplemented with selenium sources and levels, proving that there was no improvement in the tissue growth rate.

This result may have occurred due to a possible mobilization of selenoproteins in protecting the endoplasmic reticulum of cells 
against oxidative stress actions; thus, there was lesser action of selenoproteins reductase and $N$, which act as a cofactor in cell growth and DNA synthesis, as well as in apoptosis inhibition. Therefore, it acts in cell proliferation and consequently in fish muscle development
(Santos \& Fonseca, 2013). However, muscle formation and conformation for the cultivation phase remained as expected, showing that the post-larvae did not have selenium deficiency in the diets with supplementation.

\section{Table 7}

Measurement of muscle fibers from post-larvae Nile tilapia with $\mathbf{3 0}$ days of cultivation, receiving supplementation of different levels and sources of selenium in the diets

\begin{tabular}{|c|c|c|c|c|c|c|c|c|c|c|}
\hline \multirow{3}{*}{ VAR } & \multicolumn{10}{|c|}{ Selenium Sources } \\
\hline & \multicolumn{4}{|c|}{ Sodium Selenite } & \multicolumn{4}{|c|}{$\mathrm{P}>0.05$ - Contrast } & \multirow{2}{*}{ EPM } & \multirow{2}{*}{$P$} \\
\hline & 0.6 & 0.9 & 1.2 & 1.5 & 0.6 & 0.9 & 1.2 & 1.5 & & \\
\hline CFM & 29.4 & 25.6 & 28.9 & 27.8 & 27.5 & 27.9 & 25.1 & 28.6 & 2.5 & 0.46 \\
\hline DFM & 550.5 & 489.7 & 500.9 & 591.7 & 531.6 & 519.7 & 533.2 & 598.5 & 123.7 & 0.89 \\
\hline AFM & 8100.1 & 6287.4 & 7239.4 & 8251.6 & 7386.1 & 7169.8 & 6694.2 & 8810.1 & 2070.01 & 0.78 \\
\hline \multirow{2}{*}{ Effect } & \multicolumn{10}{|c|}{ Variables } \\
\hline & \multicolumn{4}{|c|}{ CFM } & \multicolumn{3}{|c|}{ DFM } & \multicolumn{3}{|c|}{ AFM } \\
\hline Level & \multicolumn{4}{|c|}{0.3989} & \multicolumn{3}{|c|}{0.5278} & \multicolumn{3}{|c|}{0.3296} \\
\hline Source & \multicolumn{4}{|c|}{0.4237} & \multicolumn{3}{|c|}{0.7884} & \multicolumn{3}{|c|}{0.952} \\
\hline $\begin{array}{l}\text { Level * } \\
\text { Source }\end{array}$ & \multicolumn{4}{|c|}{0.0664} & \multicolumn{3}{|c|}{0.977} & \multicolumn{3}{|c|}{0.8379} \\
\hline EPM & \multicolumn{4}{|c|}{2.3285} & \multicolumn{3}{|c|}{130.594} & \multicolumn{3}{|c|}{2113.472} \\
\hline
\end{tabular}

*MFL- Muscle fiber length in $(\mu \mathrm{m})$, DMF- Diameter of muscle fiber in $(\mu \mathrm{m})^{2}{ }^{2}$, MFA- Muscle fiber area, MSE- mean standard error, VAR- variables.

It can be seen from the photomicrographs of transversal cuts in the fingerling dorsal musculature supplemented with selenium yeast and sodium selenite compared to the control treatment during 30 days of culture (Figure 1) that there was no difference $(p>0.05)$ in the dimensions such as length, area and diameter of the fry muscle fibers. Therefore, selenium supplementation in the diets did not increase the fishes' muscle fibers in this development phase. 

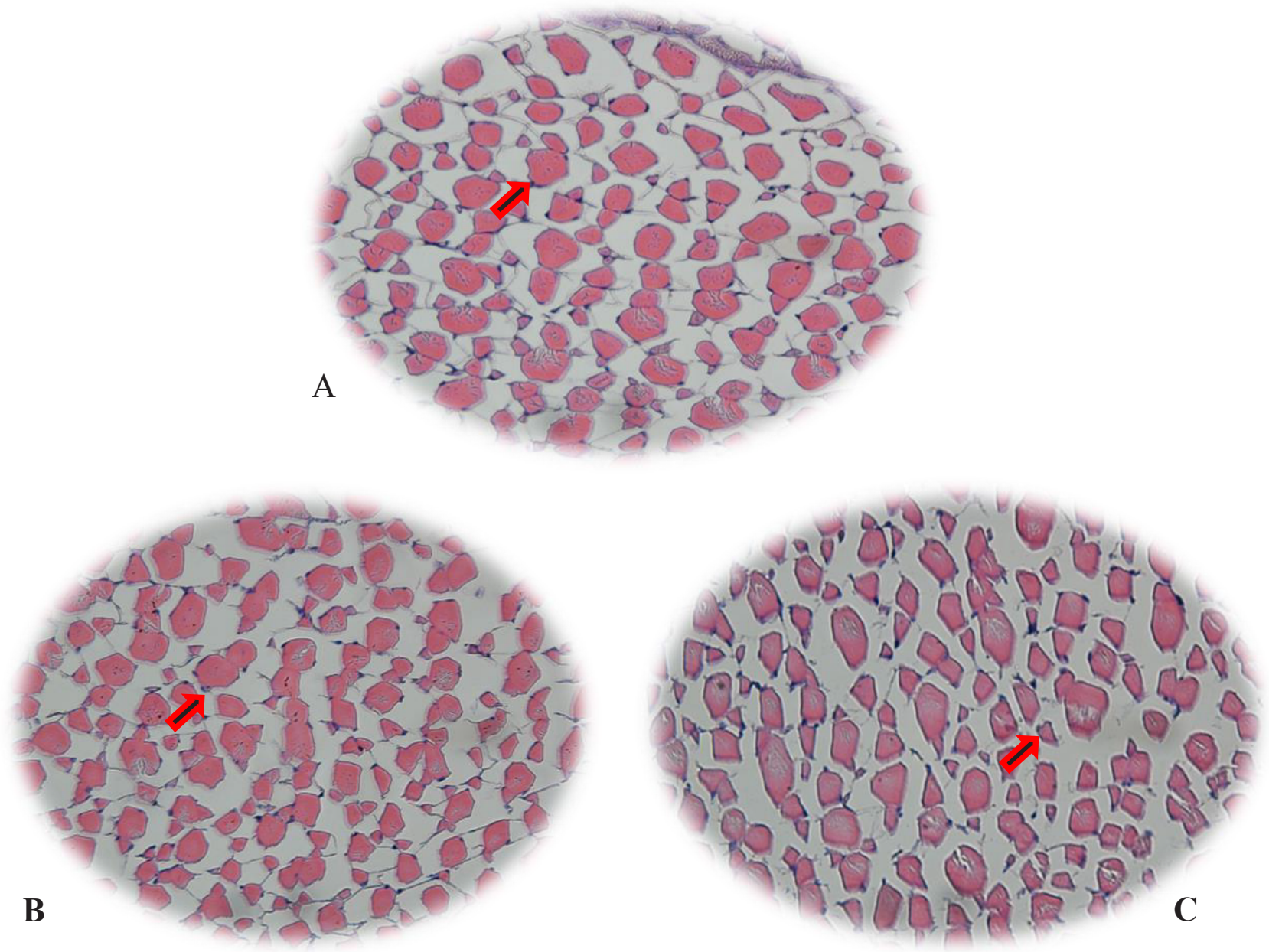

Figure 1. Photomicrograph of cross-sections of the dorsal musculature of post-larvae Nile tilapia (Oreochromis niloticus).

(A) Control treatment (exempt from dietary selenium supplementation); (B) Treatment with sodium selenite supplementation, and (C) Treatment with yeast selenium supplementation. Arrows indicate similarity in muscle fibers between treatments $(p>0.05)$. The photos were captured using optical microscopy with 400x magnification.

As we can see in Figure 1, diets supplemented with selenium maintained the fibrillar hyperplasia and hypertrophy processes through the myofibrillation mechanism, which results from the increase in the size of the pre-existing fibers, as well as the filaments due to the increase in the fiber size, thus causing cell growth in the muscle and consequently an increase in the number of muscle fibers per area (Mansour et al., 2017). These results indicate nonselenium toxicity for post-larvae Nile tilapia, not affecting the morphometry of muscle tissue, which according to (Biller-Takahashi, Takahashi, Mingatto, \& Urbinati, 2015) has a relationship with post-larvae performance. According to Y. Yamashita et al. (2010), supplementing selenium in organic form in 
fish diets presents a selenonein compound, which is the main selenium form in tilapia muscles. Therefore, the non-significant effect on the muscle fiber conformation and growth in post-larvae Nile tilapia supplemented with selenium sources may be associated with the selenium's antioxidant role, where selenium can exert an antioxidant effect by adhering to binding protein of oxygen, as in hemoglobin and myoglobin, and thereby protect fish cells from self-oxidation, and consequently less selenium action in the conformation of the fingerling muscle fibers ( $M$. Yamashita \& Yamashita, 2015). In addition, there may have been greater selenium mobilization for enzymatic activities in order to increase the physiological responses in post-larvae organisms (Le \& Fotedar, 2014).

The results of the study by Takahashi et al. (2017) suggest an ideal selenium supplementation for post-larvae fish above $1.56 \mathrm{mg}$ selenium/kg of feed. However, Khalil et al. (2019) observed a positive effect on the growth and survival of fish fingerlings with selenium supplementation using levels between $1.51,2.97$ to $3.98 \mathrm{mg}$ selenium $/ \mathrm{kg}$ of feed.

\section{Conclusion}

It is concluded that $0.6 \mathrm{mg}$ of selenium/ $\mathrm{kg}$ of the diet, regardless of the source used, met the mineral requirements for Nile tilapia during the sexual inversion period.

\section{Conflicts of Interest}

The authors declare no conflicts of interest.

\section{Acknowledgements}

This study was financed in part by the Coordenação de Aperfeiçoamento de Pessoal de Nível Superior - Brasil (CAPES). We thank the Yes Sinergy company for donating the yeast selenium used in the study.

\section{References}

Betancor, M. B., Caballero, M. J., Terova, G., Saleh, R., Atalah, E., Benitez-Santana, T.,... Izquierdo, M. (2012). Selenium inclusion decreases oxidative stress indicators and muscle injuries in sea bass larvae fed high-DHA microdiets. British Journal of Nutrition, 108(12), 2115-2128. doi: $10.1017 / S 0007114512000311$

Biller-Takahashi, J. D., Takahashi, L. S., Mingatto, F. E., \& Urbinati, E. C. (2015). The immune system is limited by oxidative stress: dietary selenium promotes optimal antioxidative status and greatest immune defense in pacu Piaractus mesopotamicus. Fish Shellfish Immunol, 47(1), 360-367. doi: 10.1016/j. fsi.2015.09.022

De Bock, M. F. S., Moraes, G. S. D. O., Almeida, R. G. D. S., Vieira, K. D. D. S., Santoro, K. R., Bicudo, Á. J. D. A., \& Molica, R. J. R. (2020). Exposure of Nile Tilapia (Oreochromis niloticus) fingerlings to a saxitoxin-producing strain of raphidiopsis (Cylindrospermopsis) raciborskii (Cyanobacterium) reduces growth performance and increases mortality rate. Environmental Toxicology and Chemistry, 39(7), 1409-1420. doi: 10.1002/etc.4728

Ferrari, J. E. C., Barros, M. M., Pezzato, L. E., Gonçalves, G. S., Hisano, H., \& Kleemann, G. 
K. (2004). Níveis de cobre em dietas para a tilápia do Nilo, Oreochromis niloticus. Acta Scientiarum. Animal Sciences, 26(4), 429-436. doi: 10.4025/actascianimsci. v26i4.1713

Furuya, W. M. (2010). Tabelas brasileiras para nutrição das Tilápias. Toledo: GFM. Recuperado de https://docplayer.com. br/7805231-Tabelas-brasileiras-para-anutricao-de-tilapias.html.

Hayashi, C., Boscolo, W. R., Soares, C. M., \& Meurer, F. (2002). Exigência de proteína digestível para larvas de Tilápia do Nilo (Oreochromis niloticus), durante a reversão sexual. Revista Brasileira Zootecnia, 31(2), 823-828. doi: 10.1590/ S1516-35982002000400003

Hung, S. W., Tu, C. Y., Wang, W. S. (2007). In vivo effects of adding singular or combined anti-oxidative vitamins and/or minerals to diets on the immune system of tilapia (Oreochromis hybrids) peripheral blood monocyte-derived, anterior kidney-derived, and spleen-derived macrophages. Veterinary Immunology and Immunopathology, 115(1-2), 87-99. doi: 10.1016/j.vetimm.2006.09.004

Jagtap, R., Maher, W., Krikowa, F., Ellwood, M. J., \& Foster, S. (2016). Measurement of selenomethionine and selenocysteine in fish tissues using HPLC-ICP-MS. Microchemical Journal, 128, 248-257. doi: 10.1016/j.microc.2016.04.021

Katarzyna, B., Taylor, R. M., Szpunar, J., Lobinski, R., \& Sunde, R. A. (2020). Identification and determination of selenocysteine, selenosugar, and other selenometabolites in turkey liver. Metallomics 12(5), 758-766. doi: 10.1039/d0mt00040j
Khalil, H. S., Mansour, A. T., Goda, A. M. A., \& Omar, E. A. (2019). Effect of selenium yeast supplementation on growth performance, feed utilization, lipid profile, liver and intestine histological changes, and economic benefit in meagre, Argyrosomus regius, fingerlings. Aquaculture, 25, 135-143. doi: 10.1016/j. aquaculture.2018.11.018

Kleemann, G. K. (2002). Exigência nutricional de ferro da tilápia do Nilo Oreochromis niloticus. Dissertação de Mestrado, Universidade Estadual Paulista, Botucatu, São Paulo, SP, Brasil. Retrieved from https:// bibdig.biblioteca.unesp.br

Le, K. T., \& Fotedar, R. (2014). Immune responses to Vibrio anguillarum in fish, Seriola lalandi, receiving selenium supplementation. Journal World Aquaculture Society, 45(2), 138-148. doi: 10.1111/jwas.12104

Lee, S., Nambi, R. W., Won, S., Katya, K., \& Bai, S. C. (2016). Dietary selenium requirement and toxicity levels in juvenile Nile tilapia, Oreochromis niloticus. Aquaculture, 464, 153-158. doi: 10.1016/j. aquaculture.2016.06.027

Lin, Y. H., \& Shiau, S. Y. (2005). Dietary selenium requirements of juvenile grouper, Epinephelus malabaricus. Aquaculture, 250(1-2), 356-363. doi: 10.1016/j. aquaculture.2005.03.022

Mansour, A. T.-E., Goda, A. A., Omar, E. A., Khalil, H. S., \& Esteban, M. A. (2017). Dietary supplementation of organic selenium improves growth, survival, antioxidant and immune status of meagre, Argyrosomus regius, juveniles. Fish and Shellfish Immunology, 68, 516-524. doi: 10.1016/j. fsi.2017.07.060 
Meurer, F., Hayashi, C., Boscolo, E. R., Schamber, C. R., \& Bombardelli, R. A. (2005). Fontes proteicas suplementadas com aminoácidos e minerais para a tilápia do Nilo durante a reversão sexual. Revista Brasileira Zootecnia, 34(1), 1-6. doi: 10.1590/S1516-35982005000100001

National Research Council - NRC. (2011) Nutrient requirements of fish and shrimp (2nd rev. ed.). Washington, D.C.: National Academy Press.

Pilarczyk, B., Tomza-Marciniak, A., Pilarczyk, R., Marciniak, A., Bąkowska, M., \& Nowakowska, E. (2019). Selenium, Se. In Mammals and Birds as Bioindicators of Trace Element Contaminations in Terrestrial Environments (pp. 301-362). Springer; Cham.

Prauchner, C. A. (2020). A importância do selênio para a agropecuária e saúde humana. Santa Maria, RS, Brasil: Fundação de Apoio a Tecnologia e Ciência-Editora UFSM.

Rathore, S. S., Murthy, H. S., Girisha, S. K., Nithin, M. S., Nasren, S., Mamun, M. A. A., \& Pai, M. (2021). Supplementation of nano-selenium in fish diet: impact on selenium assimilation and immuneregulated selenoproteome expression in monosex Nile tilapia (Oreochromis niloticus). Comparative Biochemistry and Physiology Part C: Toxicology \& Pharmacology, 240, 108907. doi: 10.10 16/j.cbpc.2020.108907

Rui, L. (2014). Energy metabolism in the liver. Comprehensive Physiology, 4(1), 177197. doi: $10.1002 /$ cphy.c130024

Santos, C. E., \& Fonseca, J. (2013). Selénio: fisiopatologia clínica e nutrição.
Associação Portuguesa de Nutrição Entérica e Parentérica, 7(1), 2-9.

Schram, E., Pedrero, Z., Cámara, C., Heul, J. W. V. D., \& Luten, J. B. (2008). Enrichment of African catfish with functional selenium originating from garlic. Aquacultura, 39(8), 850-860. doi: 10.1111/j.1365-2109.2008. 01938.x

Schrauzer, G. N. (2001). Commentary: nutrition selenium supplements: product types, quality, and safety. Journal College of Nutrition, 20(1), 1-4. doi: 10. 1080/07315724.2001.10719007

Schulter, E. P., \& Vieira, J. E. R., Fo. (2018). Desenvolvimento e potencial da tilapicultura no Brasil. Revista de Economia e Agronegócio, 16(2), 177-201. doi: 10.25070/rea.v16i2.554

Sele, V., Ornsrud, R., Sloth, J., Berntssen, M. H. G., \& Amlund, H. (2018). Selenium and selenium species in feeds and muscle tissue of Atlantic salmon. Journal of Trace Flements in Medicine and Biology, 47, 124133. doi: 10.1016/j.jtemb.2018.02.005

Silva, D. R. P. D. (2015). Adição de L-glutamina+ ácido glutâmico e L-argenina na dieta de leitões recém desmamados. Dissertação de mestrado em Produção de não ruminantes, Universidade Federal da Paraíba, campus II, Areia, PB, Brasil. Recuperado de https://repositorio.ufpb. br/jspui/handle/123456789/15865

Takahashi, L. S., Biller-Takahashi, J. D., Mansano, C. F. M., Urbinati, E. C., Gimbo, R. Y., \& Saita, R. V. (2017). Saita, longterm organic selenium supplementation overcomes the trade-off 538 between immune and antioxidant systems in pacu (Piaractus mesopotamicus), Fish 539. 
Shellfish Immunology, 60, 311-317. doi: 10.1016/j.fsi.2016.11.060

Wang, L., Zhang, X., Wu, L., Lui, Q., Zhang, D., \& Yin, J. (2018). Expression of selenoprotein genes in muscle is crucial for the growth of rainbow trout (Oncorhynchus mykiss) fed diets supplemented with selenium yeast. Aquaculture, 492, 82-90. doi: 10.1016/j. aquaculture.2018.03.054

Yamamoto, F. Y. (2011). Microminerais (Cu, $\mathrm{Fe}, \mathrm{Mn}$, Se e $\mathrm{Zn}$ ) na nutrição de peixes, uma revisão bibliográfica. Trabalho de Conclusão de Curso Apresentado no Curso de Engenharia de Aquicultura, Centro de Ciências Agrárias, Universidade Federal de Santa Catarina Florianópolis/SC - Brasil. Recuperado de http://repositorio.ufsc.br/xmlui/handle/ $123456789 / 25605$

Yamashita, M., \& Yamashita, Y. (2015). Selenoneine in marine organisms. In S.K. Kim (Ed.), Springer manual of marine biotechnology (pp. 1059-1069). Berlin, Heidelberg: Springer.
Yamashita, Y., Yabu, T., \& Yamashita, M. (2010) Discovering the strong antioxidant selenonein in the metabolism of selenium tuna and redox, World Journal of Biological Chemistry, 1(5), 144-150. doi: 10.4331/ wjbc.v1.i5.144

Zhan, X. A., Wang, M., Zhao, R. Q., Li, W. F., \& Xu, Z. R. (2007). Effects of different selenium source on selenium distribution, loin quality and antioxidant status in finishing pigs. Animal Feed Science and Technology 132(3-4), 202-211. doi: 10.10 16/j.anifeedsci.2006.03.020

Zhang, H., Feng, X. B., Chan, H. M., \& Larssen, T. (2014). New insights into traditional health risk assessments of mercury exposure: implications of selenium. Environmental Science \& Technology, 48(2), 1206-1212. doi: $10.1021 /$ es4051082 
